\title{
OBSERVATIONS ON THE EUCALYPTS OF NEW SOUTH WALES.
}

By Henry Deane, M.A., F.L.S., ¿c., and J.H. Maiden, F.L.S., \&C.

(The Illustrations by R. T. Baker, F.L.S.)

\section{Part II.}

\section{(Plates LIX.-LXI.)}

The Eucalypts dealt with in this Part fall naturally into a single group distinguished chiefly by the fibrous and tenacious character of the bark, and to some extent by the length and straightness of the grain of the wood. They go under the vernacular names of Stringybark and Messmate.

The Stringybarks proper are E. capitellata, E. macrorrhyncha, and $E$.eugenioides. These three species, although in their typical forms so distinct, have connecting links, and in the case of some of these varieties it is often difficult to decide under which species to place them.

E. obliqua and E. fastigata (Cut-tail) are Messmates, the former being sometimes called Stringybark.

There is another species in New South Wales, E. Baileyana, which is said to be called Stringybark, but we propose to postpone consideration of this species, as well as of other fibrous-barked species, E. acmenoides, White Mahogany (sometimes called Stringybark), E. microcorys, Tallow wood, and E. pilularis, Blackbutt, to some future occasion.

\section{Eucalyptus capitellata, Sm.}

Smith's original description and notes on this species are as follows :-

"Eucalyptus capitellata, operculo conico calyceque anguloso subancipiti, capitulis lateralibus pedunculatis solitariis. 
"Lid conical, and, as well as the calyx, angular, and somewhat two-edged. Heads of flowers lateral, solitary, on flower-stalks.

"The leaves are ovate-lanceolate, firm, astringent, but not very aromatic. We have seen no other species in which the flowers stand in little dense heads, each flower not being pedicellated so as to form an umbel. The lid is about as long as the calyx. Flower-stalk compressed, always solitary and simple.

"The fruit of this species, standing on part of a branch whose leaves are fallen off, is figured in Mr. White's 'Voyage,' p. 226, along with the leaves of the next species." ("Botany of New Holland,' p. 42).

The description was marle from plants procured in the neighbourhood of Sydney.

Vernacular names._- "Red Stringybark" is a name generally applied to this species in this colony in allusion to the darker colour of the wood as compared with that of $E$. engenioides, White Stringybark. It also goes under the name of "Broad-leaved Stringybark." In the Walcha district it appears to be confused with Red Mahogany.

Seedling or sucker leaves.-These are well represented in Howitt's 'Eucalypts of Gippsland,' Pl. 14 (Trans. Roy. Soc. Vict. ii.). Like those of E. macrorrhyncha and E. eugenioides, they are placed opposite one another at an early stage, but very soon become alternate. The young shoots are warty.

Mature leaves.-They are very coriaceous, even when grown at a considerable distance from the sea. The leaves are larger and coarser than those of two other Stringybarks (E. macrorrhyncha and $E$. eugenioides), and very oblique.

Buds. - The buds and peduncles are generallys somewhat thick and angular or flattened, and contrast with the neatness of shape of those of E. eugenioides and E. macrorrhyncha. In some cases, however, the buds are round, symmetrical and plump, and resemble more nearly those of $E$. engenioides.

Flowers.-The filaments of the anthers sometimes dry dark.

Fruits.-In consequence of the fruits being sessile or nearly so and crowded into heads, they assume a polygonal shape at the 
base as if they had been pressed together when in a plastic condition. With this exception, the fruits have the form of a very much compressed spheroid, the horizontal diameter of which is from $1 \frac{1}{2}$ times to twice the depth. The fruit is swollen out below the rim, which is sometimes very well defined and of a red or brown colour. The fruit is sometimes truncate, but more frequently the rim is dome-shaped.

There is great variability in the amount of the exsertion of the valves. In an example from $W$ allsend in which the inflorescence has the same character as the Sydney form, the fruits are smaller, less compressed, and the valves more exserted.

Timber.-The wood, as already stated, is open, somewhat reddish, and darker than that of $E$. eugenioides. It stands well in the ground and is otherwise durable. It is very suitable for building purposes, but is rery free.

Range.-Howitt states in his 'Eucalypts of Gippsland' that he has not seen it growing at a less elevation than 500 feet, and that it cannot therefore strictly speaking be called one of the littoral species. In this colony, however, it is found growing quite close to the sea; for instance, on the shores of Sydney harbour, and from the coast inland to the summit of the Dividing Range. The most northerly locality from which we have it is the Round Mountain, Guy Fawkes Range, 4250 feet above the sea, and about 50 miles east of Armidale, on the Grafton Road.

The most westerly locality from which it has been obtained is Mudgee, where it is called "Silvertop" according to Mr. R. T. Baker, who collected it.

Variations from type.-The most remarkable known to us is perhaps one from the Port Stephens district, where together with the normal form is one apparently similar in every respect except as to greatly diminished size. Variations exist also as to length of pedicel and amount of compression of the fruits into heads.

Eucalyptus macrorrhyncha, F.v.M.

This in its typical form is a very easily recognised species. The buds are, when fully developed, large, rhomboidal in longitudinal 
section, with pointed operculum, and the pedicels are long, so that the flowers and fruits form loose heads.

Vernacular names.-It is usually known as "Stringybark" merely, but by comparison with $E$. eugenioides as "Red Stringybark." According to Howitt, it is known as "Mountain Stringybark" in Gippsland, a name to which in this colony the other Stringybarks have also some claim. E. macrorrhyncha, however, appears to be quite absent from the coast districts.

Seedling or sucker leaves.-The remarks made under E. capitellata apply equally to this species.

Mature leaves. - These are coriaceous and much resemble those of E. capitellata.

Buds.-These are strongly pedicellate, and the edge of the calyx tube forms a prominent ring, while the operculum is acuminate and often lengthened out into a point. In the matter of shape one cannot help likening them to those of $E$. rostrata, which, however, are very small in comparison.

Fruits. - These vary somewhat in shape and size, but owing to the long pedicels, the prominent edge to the rim, and the domed top, they can always be recognised. A particularly large-fruited form has been collected by $\mathrm{Mr}$ R. T. Baker in the Rylstone district, where trees with fruits of ordinary size are also found. The remark about the buds as to their resemblance in shape to those of $E$. rostrata applies here also.

Timber. - This seems in every respect to resemble that of $E$. capitellata.

Range.-In Gippsland this is essentially a mountain species, and Mr. Howitt has not seen it growing at a lower elevation than 200 feet. In this colony it is found along the Dividing Range and Table Land from New England in the north. We have it from Mt. Wilson, from Yass, and from near Delegate. It grows down the western slopes and on the spurs of the main range and on the isolated ranges some distance into the interior. The most westerly localities actually recorded are Mudgee and Grenfell. 
That $E$. capitellata and $E$. macrorrhyncha possess points of resemblance is apparent to the most superficial observer. A comparison of the two may be roughly tabulated as follows :-

E. capitellata-Operculum obtuse. Flowers and fruits sessile or nearly so. Fruit expanded below the rim.

E. macrorrhyncha.-Operculum acuminate or conical. Flowers and fruits strongly pedicellate; calyx border prominent.

But these characters are not absolute, and only belong to the types, considerable variation occurring in some specimens.

Baron von Mueller in the 'Eucalyptographia,' under E. macrorihyncha, says :-

"E. macrorrhyncha stands nearest to E. capitellata; leaves and fruits of both are the same; but the flowers of the latter are always sessile or nearly so and thus crowded into heads as the species name signifies, besides being usually smaller; the lid of $E$. capitellata is hemispheric, without any prominent point, and shorter in proportion to the tube, the latter being also more angular and downward less attenuated."

With all respect to the very high authority of Baron von Mueller, we cannot agree that the fruits of $E$. capitellata and $E$. macrorrhyncha are the same; and a study of the figures of the two species in the 'Eucalyptographia' will prove the inaccuracy of the statement; we, however, show that there are intermediate forms.

Under E. macrorrhyncha in the 'Flora Australiensis' we find:-

"Var. (?) brachycorys. Operculum short and obtuse. Fruit of E. macrorrhyncha. Expanded flowers not seen, and therefore affinities uncertain. New England. "Stringybark." (B.Fl. iii. $207)$.

The Eucalypt thus referred to by Bentham is evidently one of those connecting links between capitellata and macrorrhyncha, of which we possess specimens, but we doubt the expediency of giving names to any of these numerous varieties until our knowledge concerning them is more advanced.

Although the fruit of $E$. capitellata is usually sessile, or nearly so, we have specimens which are distinctly stalked. If these 
forms be examined in fruit only (without reference to the buds), they may be readily mistaken for $E$. macrorrhyncha.

Usually, however, these connecting links between capitellata and macrorrhyncha show a leaning towards the type of either one species or the other, so that we may conveniently classify them, but in regard to the following tree we are unable to place it with either one species or the other. It is the tree found on the Gulf Road, Rylstone district, and attributed to $E$. obliqua by R. T. Baker, Proc. Linn. Soc. N.S.W. 1896, p. 446.

The buds resemble those of E. eugenioides. The fruits are shortly pedicellate, and in that respect approach $E$. macrorrhyncha, but otherwise they are hemispherical and flat-topped like many specimens of E.eugenioides, but there is a distinct and sharp edge or rim, with a tendency to doming, like $E$. macrorrhyncha. The valves are only slightly exserted. The buds appear to us dissimilar to those of $E$. obliqua, and the fruits are too broad and hemispherical for that species, the only real resemblance to $E$. obliqua existing in the leaves, which, however, equally resemble $E$. capitellata.

We have specimens collected by Mr. Augustus Rudder in the same district and named by him "Mountain Stringybark." They have fruits with slightly longer pedicels and many of them are more of a domed character, but on the same twig with these somewhat dome-shaped fruits are other fruits precisely similar to those from the Gulf Road. We are quite of opinion that they are from identical trees, and would on no account place them under E. obliqua.

Should it be found necessary, on account of persistence of characters over a large area, to separate this tree from capitellatamacrorrhyncha (it being desirable, in our opinion, to look upon it as a connecting link between these species, for the present), it would perhaps be advisable to give it specific rank.

\section{Eucalyptus eugenioides, Sieb.}

Sieber's definition of $E$. eugenioides (Sprengel's Curæ Posteriores iv. 195), is as follows :- 
"E. operculo mucronulato, umbellis lateralibus racemosis, ramulis teretibus, foliis inæqualiter oblongo-lanceolatis," a description which would have rendered it impossible to state what species was meant had not a specimen, named by Sieber, been in existence.

Vernacular names.-It is usually known as "White Stringybark" in this colony, the colour of its timber being paler than that of either E. capitellata or E. macrorrhyncha.

Seedling or sucker leaves. - These are well represented in the 'Eucalyptographia' and in Howitt's 'Eucalypts of Gippsland.' The young shoots are warty and the leaves, which at first are placed opposite to one another, soon become alternate.

Mature leaves. - These are generally much thinner and more delicate in texture than those of E. captellata and E. macrorrhyncha. They are also of a richer green, more shapely, graceful and Eugenia-like, a circumstance which led to the adoption probably of the specific name. Exceptions, however, occur, and specimens in our possession from Wallsend and Mudgee are coriaceous and shiny.

Buds. - The buds are clustered and often very much crowded into heads, by which the inflorescence assumes a very marked character. They always have pointed opercula, the points being sometimes so marked as to approach those of $E$. macrorrhyncha, but they are then fuller on the top and do not show such a prominent edge at the base of the operculum.

Fruits. - The fruits are slightly pedicellate, often crowded into more or less globular heads, but not compressed like those of E. capitellata. They are much smaller than those of the allied species, somewhat hemispherical in form, with slightly raised rim. Occasionally the fruit is quite flat-topped. The rim is often red.

The plate in the 'Eucalyptographia' shews a very thin rim, which is most unusual and not typical of the species, at least in New South Wales, but we have an example of this form from Port Macquarie.

Timber.-The timber of this species is good for building purposes, being strong and durable and not particularly liable to 
warp. It is often considered, as at Mudgee, superior to "Red Stringybark" (E. macrorrhyncha).

Range.-Coast district and tableland throughout, and extending westerly as far as Mudgee, though apparently not so abundant as E. macrorrhyncha.

In the 'Flora Australiensis' E. eugenioides is reduced to a variety of $E$. piperita, but it has since been shown to be an undoubtedly good species, its affinities being more with $E$. capitellara than with E. piperita. From the latter it is easily distinguished in the living state by the strong fibrous character of the bark which extends to the small branches, the other species having a bark of the texture of $E$. amygdalinr, and being only half-barked in general like E. pilula is. The fruits of E. piperita are more contracted at the top with a thin rim, whereas those of E. eugenioides have a well-marked rim, sometimes flat but generally raised.

We have leaves and fruits of a very interesting Stringybark from the Glen Innes district (Hartley's Mill). We refer the plant to E. eugenioides in the absence of complete material. The fruits are larger than those of $E$. engenioides usually are, and have a well-defined prominent rim, grooved on the outer edge, and show a tendency to exsertion of the valves.

E. capitellata and E. engenioides are very intimately related. Besides their relation as Stringybarks, we have trees with fruits so shaped that it is not entirely satisfactory to refer them to either species.

Some fruits show a tendency to $E$. capitellata in having fruits larger and more "squatty" or compressed than those of $E$. engenioides. But the valves of the fruits are not exserted, nor are the buds so flat and angular as those of $E$. capitellata usually are. The buds are, in fact, those of E. eugenioides. The precise shape of the fruits will be seen on reference to the figure (Pl. Lx. fig. 1). These intermediate forms are common on the Southern Dividing Range and the Blue Mountains. On both ranges we have typical ergenioides and capitellata, together with the intermediate forms alluded to. 
E. engenioides displays a tendency to form globular masses of alosely packed sessile fruits, after the manner of $E$. capitellata (see Pl. Lx. fig. 5). These globular masses present such a different appearance to the ordinary form of E. eugenioides that they may, at first sight, be reasonably supposed to form a variety, but we have many gradations between them and the ordinary form.

This head-flowered form may, perhaps, be looked upon as exuberance of growth arising from unusual vitality of a plant.

At Hilltop, near Mittagong, there is a variety locally known as "Blueleaf Stringybark." It appears to be confined to a few of the gullies about there. It is so called because the leaves, especially in the sunlight, are observed to have a bluish cast, and this bluish appearance (especially noticeable in the young leaves), is largely retained on drying for the herbarium. The tops of the trees can be readily noticed, amongst the other foliage, from a neighbouring eminence. The fruits are in spherical clusters, and if it were desirable to distinguish this tree as a variety of 'eugenioides, the name agglomerita would be very suitable. (See Agric. Gazette N.S.W. vii. 268, May, 1896.)

\section{E. obliqua, L'Her.}

Although this species is so well-known in Victoria and Tasmania, its occurrence in New South Wales has scarcely been observed by botanists. Yet it is a fine well-developed forest tree in the south-eastern district, and the timber is sawn up and finds a ready market.

Vernacular names.-It is usually known as "Stringybark" in Tasmania and South Australia, and to a less extent in Victoria; in the last colony, however, it is usually known as "Messmate," because it is associated with other Stringybarks and fibrousbarked Eucalypts. The same name is in use in southern New South Wales, as for instance at Sugar Loaf Mountain, Braidwood; and at Tantawanglo Mountain, near Cathcart. Apparently this is the most widely used name for it in New South Wales, and the term "Stringybark" does not seem to be ever applied to it in this colony. 
Because it is usually rough-barked to the ends of the branches, it sometimes goes by the name of "Woolly-topped Messmate" in the Braid wood district (Monga, \&c.).

Seedling or sucker leaves.-Broadly ovate, somewhat cordate, tending to become unequal, but not always so, and apparently always attenuate, as pointed out by Howitt. Venation well marked and more transverse than in the foliage of the mature tree.

Leaves of mature trees.-It is a coarse-foliaged tree, by which characteristic alone it can usually be distinguished from those species with which it is usually associated, or with which it is likely to be confused. Its strikingly oblique, unsymmetrical leaves have no doubt given origin to its name. Obliquity is a character of nearly all Eucalypt leaves, but in the species under consideration and in E. capitellata it is particularly observable. The leaves are sometimes dotted and channelled like E. stellulata (see Part i. p. 598).

Fruit.-A figure of the usual Victorian form will be found in the 'Eucalyptographia;' we give a representation of the fruit as found in the southern mountain ranges in this colony.

The orifice is sometimes a little contracted, reminding one, in this respect, and in its general shape of the capsule, of some forms of $E$. piperita, but it is larger than the fruit of that species. Drying accentuates the contraction of the orifice in both. The two may be at once separated by the venation and shape of the leaves, shape of the buds, \&c., but the two species approach one another sometimes very closely in the shape of the fruits.

The fruits in the southern parts of this, colony are subcylindrical in shape, while those of the Victorian specimens, figured in the 'Eucalyptographia,' are more hemispherical.

The fruits of $E$. gigantea, Hook. f. ('The Botany of the Antarctic Voyage;' Hooker, 'Flora Tasmaniæ,' t. 28) usually referred to E. obliqua, and doubtless correctly, are more pearshaped, and with valves more sunk, than we have observed in the New South Wales specimens. 
Bark.--Rough-barked to the ends of the branches; the bark of the trunk and branches is decidedly fibrous, but the fibres are not so clean and tenacious as those of the true Stringybarks, and the bark is not so suitable for roofing.

Timber.-Timber from New South Wales localities is a rather inferior, coarse, open-grained porous wood, liable to shrink and warp. It is not esteemed for public works. Its open nature may be, at least in part, a consequence of rapid growth, for which, according to several authorities, $E$. obliqua has the reputation.

It has been used in the Braidwood and Cooma districts for many years for building purposes. In Victoria and Tasmania it is largely used, and a recent official publication of the latter colony states "It is our most valuable wood." In considering the value of this statement it should, of course, be borne in mind that neither of these colonies possesses a series of excellent timbers such as New South Wales can boast of.

Range.-Chiefly a Tasmanian and Victorian tree, it is abundant in many places along the top of the eastern slope of the coast range from Braidwood south. Its northernmost limit is a matter for further investigation, but it extends nearly to the Clyde River. It is found growing in company with E. yoniocalyx and other species on the Irish Corner Mountain, Reidsdale, Sugar Loaf Mountain, and around Monga, both on the eastern and western fall of those mountains. The trees are fairly abundant, and are to be found growing to a height of from 100 to 150 feet, with a girth of from 6 to 10 feet.

Howitt (Trans. Roy. Soc. Vict. ii. Pt. i, 1890, p. 92) makes the statement, as regards Gippsland, that "It appears to be essentially a littoral form, but ascends the mountains, dc."

The first part of this statement does not appear to hold true in New South Wales. The tree grows right on the top of the southern range with us and never in the littoral lands, as far as observed. It frequents situations where it can be reached and enveloped in the sea-fogs; in this remote sense alone can the word "littoral" be applied to the trees with us.

On the Tantawanglo Mountain it grows abundantly in company with "Cut-tail" and other Eucalypts at a height of about 3000 
feet above the sea. At Reidsdale it occurs at an elevation of from 2000 to 2500 feet.

E. obliqua has never been positively recorded from north of Sydney; in fact, its recognised localities are many miles to the south. Nevertheless, we have a specimen undoubtedly, in our opinion, belonging to this species, obtained by an experienced collector in the ranges in the Upper Williams River district. The precise locality is unfortunately lost, and therefore we do not wish to do more than invite the attention of botanists to the desirability of searching for E. obliqua in the district named. The collector is Mr. Augustus Rudder, formerly forester of the district, whose recollection is perfectly clear in regard to the specimen referred to.

The Eucalypt from Gulf Road, Rylstone district (R. T. Baker, 'Proc. Linn. Soc. N.S.W.' 1896, p. 446) we have discussed under E. macrorrhyncha (ante, p. 803).

The following description of E. obliqua from Sir J. E. Smith's 'Specimen of the Botany of New Holland,' p. 43 (London, 1793), is interesting, and may be convenient for reference:-

"Eucalyptus. obliqua, operculo hemisphærico mucronulato, umbellis lateralibus solitariis; pedunculis ramulisque teretibus.

"Lid hemispherical, with a little point. Umbels lateral, solitary; flower-stalks and young branches round.

"Syn. E obliqua, Ait. Hort. Kew. v. 2, 157 ; L' Herit. Sert. Angl. t. 20."

"From the only specimen we have seen of this, which is in Sir Joseph Banks' herbarium, it appears the branches are all round to the very top. General flowering-stalks round, the partial ones only slightly angular, not compressed. Bark rough from the scaling off of the cuticle, but this may be an unnatural appearance. Leaves ovate-lanceolate, aromatic, but without the flavour of peppermint."

\section{E. Fastigata, n.sp.}

I.troductory.-While dealing with the Stringybark group we draw attention to a tree which is very closely related to one of them, and is, to all intents and purposes, a Stringybark. We 
allude to the forest tree known as Cut-tail in the southern part of the colony. It attains a height of 60-100 feet and more, and a diameter of at least 4 feet. Its affinities to other species will be dealt with under various headings, but we may point out that it strongly resembles $E$. obliqua in bark and wood, while the two species have very dissimilar buds and fruits. The only point of resemblance to $E$. amygdalina lies in the fruits, which are rather like those of our variety latifolia figured in our former paper of this series.

We do not hesitate to say that "Cut-tail " cannot be included under any existing species, and therefore propose the name fastigata for it, in allusion to the shape of the operculum and leaves.

Vernacular names. - Several names are more or less in use in different places. The one most in use, where also the tree is best developed, is "Cut-tail," and inasmuch as this name is not applied to any other tree, so far as we are aware, we would suggest that all other English names be dropped as far as possible in favour of this. We have made many enquiries as to the meaning of the term "Cut-tail," but without success, and can only suggest that it has reference to the rough bark on the branches which in comparison with $E$. obliqua, which it so much resembles in general appearance, it is cut-tailed or curtailed.

Other names that have been mentioned to us for this tree are "Blackbutt," on the Nimbo Station, Braidwood-Cooma Road, and, on the Tantawanglo Mountain, "Messmate." "White-topped Messmate" and "Silvertop" at various places, and "Brownbarrel " at Queanbeyan."

Seerling or sucker leaves.-Ovate-lanceolate, early becoming oblique; scattered, in this respect very dissimilar to those of $E$. amygdalina, the leaves of which remain opposite until the tree has attained some size. The veining of the under side prominent. The twigs rusty tuberculate like E. amygdalina and some other species.

Leaves of mature trees.-Lanceolate, and when fully grown narrow-lanceolate. Often more or less ovate-lanceolate, and 
always more or less attenuate. They are rather coriaceous, smooth and rather shining. They possess no odour of peppermint.

Buds.-The chief characteristic is the shortly acuminate operculum, which is much accentuated in dried specimens. In $k$. obliqua the operculum is blunt, and the whole bud club-shaped, very different to those of the species now under review.

The anthers are partly folded in the bud.

Fruits. - The figure (Pl. LxI.) will make the shape clear. They are pear-shaped, have a conical or domed rim, with the valves somewhat exserted. They are always 3-celled as far as seen. Diameter of $\operatorname{rim} 2 \frac{1}{2}$ to nearly 3 lines. Length from end of pedicel to rim $2 \frac{1}{2}$ lines.

The fruit differs from that of $E$. obliqua in being more or less conical, while, that of $E$. obliqua is subcylindrical. The latter species has no well defined rim and the valves are sunk, whereas in the tree now under consideration there is a prominent rim, while the valves are somewhat exserted. The fruits of E. obliqua are also larger than those of our species and have shorter stalks. In the latter species the peduncles are elongated over half an inch in fruit, and are distinctly pedicellate, about $1 \frac{1}{2}$ lines.

Bark.-It resembles closely that of $E$. obliqua, the principal difference between the two trees, in this respect, consisting in the fact that the tops and the branches of "Cut-tail" are smooth, while those of $E$. obliqua are the reverse.

Timber.- It has all the characteristics of the timber of $E$. obliqua, from which it is scarcely, or not at all, to be distinguished. At Montgomery's mill on the Tantawanglo Mountain, near Cathcart, the two trees are considered of equal value, and the timbers of the two cut up and sold as one and the same.

Range. - The coast range from Tantawanglo Mountain to near Braidwood, so far as observed at present. Specific localities are:-Tantawanglo Mountain, growing with E. obliqua and $E$. goniocalyx; Nimbo (head of Queanbeyan River), mixed with stellate variety of $E$ : goniocalyx; Braidwood district (Reidsdale, Irish Corner Mountain), with E. obliqua and E. goniocalyx.

We have not yet determined whether it occurs to the west of the Dividing Range. 


\section{EXPLANATION OF PLATES.}

\section{Plate lix.}

E. macrorrhyncha.

Fig. 1.-Fruit from Yass.

Fig. 2. - Fruit from Bendigo, Victoria.

Fig. 3.-Fruit from Albury.

Fig. 4. Fig. 5. Fruits from Rylstone; No. 5 is especially large.

Fig. 6.-Umbel and young buds.

Fig. 7. Types of the angular buds, with beaked opercula. From Fig. 7A. Rylstone.

\section{E. capitellata.}

Figs. $S$ and 8A.-Fruits and buds of common Sydney form (Mosman's Bay). Fig. 9.-Fruits from Kalgoola, Mudgee district.

Fig. 10.-Fruits from Mt. Victoria, showing flattened top or truncate rim and lateral compression.

Fig. 11.-Eruits from Round Mountain, New England.

Fig. 12. Fruits intermediate in character between $E$. capitellata and $E$.

Fig. 13. 1 eugenioides, from Stroud and Hill Top (Mittagong) respectively. Fig. 14. - Buds of E. capitellata, showing a less flattened form than usual. Fig. 15. - Fruits depicted in White's 'Voyage,' p. 226, as E. piperita, but described by Smith, Trans. Linn. Soc. iii. 285 (1797), as E. capitellata.

\section{Plate lix.}

\section{E. eugenioides.}

Fig. 1.-- Fruits from Mt, Victoria.

Fig. 2.-Fruits from Tweed Ruver, showing slightly exserted valves.

Fig. 3. - Fruits fr. m Ulladulla, showing hemispherical shape.

Fig. 4.-Fruits from Bega, showing sessile character.

Fig. 5. - Fruits from Cabramattia, near Sydney, showing disposition into a dense globular head.

Fig. 6.-Fruits from Homebush, near Sydney, showing pilular shape and sunk rim.

Fig. 7.-Fruits from Hogan's Brush, near Gosford, unusually large in size, and with well-defined rim. Intermediate in character between this species and E. capitellata: Cf. Plate LIX.. figs. 12 and 13.

Fig. 8. - Normal buds of E. eugenioides.

Fig. 9.-Fruits.

$$
\text { E. obliqua. }
$$

Fig. 10.-Leaf showing oblique outline, and venation. 
Fig. 11. ) Fruits and buds of the Eucalypt provisionally placed between $E$.

Fig. 12. capitellata and E. macrorrhyncha (Gulf Road, R. T. Baker; also Mr. Rudder's specimen).

Plate lixi.

E. fastigata, sp.nov.

Fig. 1.-Seedling foliage.

Fig. 2.-Twig in bud.

Fig. 3.-Mature leaf, showing venation.

Fig. 4.--Fruit, showing exserted valves.

Fig. 5.-Transverse seetion of fruit. 


\section{$2 \mathrm{BHL}$ Biodiversity Heritage Library}

Deane, $\mathrm{H}$ and Maiden, J. H. 1897. "Observations on the eucalypts of New South Wales. Part II." Proceedings of the Linnean Society of New South Wales 21, 798-813. https://doi.org/10.5962/bhl.part.8496.

View This Item Online: https://www.biodiversitylibrary.org/item/30483

DOI: https://doi.org/10.5962/bhl.part.8496

Permalink: https://www.biodiversitylibrary.org/partpdf/8496

\section{Holding Institution}

MBLWHOI Library

\section{Sponsored by}

MBLWHOI Library

\section{Copyright \& Reuse}

Copyright Status: NOT_IN_COPYRIGHT

This document was created from content at the Biodiversity Heritage Library, the world's largest open access digital library for biodiversity literature and archives. Visit BHL at https://www.biodiversitylibrary.org. 